\title{
Improvement of organizational and economic mechanism of development of ecological tourism
}

\author{
Islamova Risolat Abdullaevna ${ }^{1}$ \\ ${ }^{1}$ Navoi State Mining Institute, Republic of Uzbekistan \\ Email: islamova_r@umail.uz
}

\begin{abstract}
This paper makes analyses of the research on the improvement of organizational and economic mechanism of development of ecological tourism. On this case, research analyses make investigates in the evidences of the Republic of Uzbekistan. Moreover, its different research points were discussed both methodologically and theoretically. Finally, research concludes with major conclusions for the further developments.
\end{abstract}

Keywords: Tourism, eco-tourism, analyses, case of Uzbekistan, new plans, strategic development.

\section{INTRODUCTION}

Research based on the analytical points of the decrees from December 2, 2016 President of the Republic of Uzbekistan and Decree of the President of the Republic of Uzbekistan "On measures to ensure rapid development of the tourism industry of the Republic of Uzbekistan"

Resolution by the President of the Republic of Uzbekistan No. PP-3217 dated August 16, 2017 "On additional organizational measures to create favorable conditions for the development of tourism potential of the Republic of Uzbekistan" Decree of the President of the Republic of Uzbekistan dated February 6, 2018 No PP3509 "On measures to ensure accelerated development of internal tourism" of February 6, 2018 "On January 5, 3514, No. 2019," the rapid development of tourism in the Republic of Uzbekistan "On additional measures to No. PP-4095. Dozens of decrees and resolutions have also been adopted on free economic zones. At present, there are 14 free economic zones in 14 regions of the country. All of the above-mentioned normative-legal acts should be aimed at improving the organizational and economic mechanisms for the development of eco-tourism, especially in the free economic zone(Kalpakjian \& Schmid, 2014; Page, 1994; Sahadeo \& Zanca, 2007; Simpfendorfer, 2011).

One of the main types of tourism is eco-tourism, which is unique in comparison with other types of tourism. According to the World Tourism Organization, eco-tourism has become one of the fastest growing tourism destinations. Today, even in areas with free economic zones, special attention is paid to the development of tourism. "According to international organizations, there are more than 3.5 thousand free economic zones in nearly 140 countries. About 70 million people work in the free economic zones around the world. "The development of eco-tourism in the world is also important for our country. Because a number of state and regional programs for the promotion of tourism as a leading sector of the economy have been developed and are being implemented. Their main purpose is to attract more foreign tourists to our country, to turn the tourism business into a profitable sector, to improve the training of specialists, to enter the world market with competitive and strong tourism(di Cugno, Mantellini, \& Berdimuradov, 2013; Novak \& Schwabe, 2009; Sobirov, 2018a).

\section{MAIN PART}

It is necessary to consider the ways of analyzing the state of ecological tourism in Navoi region and to consider that the formation of the free economic zone is the main factor for the development of tourism; An analysis of the existing tourist routes in the region shows that most of them begin with Samarkand and Bukhara, and in some cases, Tashkent. Thus, tourists arriving in the region are formed by tourist firms in these cities and accordingly, their income is transferred to their account. This can be explained by the following data (Table 1).

As you can see, the tourist routes currently arriving in the region are mostly from other regions and are partly in the region. For example, out of the 5 available routes, only three cases stay overnight in the region. $\mathrm{He}$ only feeds once or twice during the rest. In this case, it is very difficult to increase the types of tourism services 
and cash (foreign exchange) revenues from tourism. It should be noted that the newly developed routes also start with other regions.

Table 1. Current routes in Navoi region and their timelines ${ }^{1}$

\begin{tabular}{|l|l|l|l|}
\hline & The names of tourist routes & $\begin{array}{l}\text { How long is } \\
\text { it? }\end{array}$ & Night \\
\hline & $\begin{array}{l}\text { Download Bukhara - Sarmishsoy - } \\
\text { Nurota (Chashma) }\end{array}$ & 1 day route \\
& $\begin{array}{l}\text { Bukhara - Sarmishsay - Nurota } \\
\text { (Chashma) - Aydarkul }\end{array}$ & In Bukhara: Hotel \\
\hline $\begin{array}{l}\text { Download Samarkand - Sarmishsoy - } \\
\text { Nurota (Chashma) }\end{array}$ & 1 day route & In Bukhara: Hotel, \\
\hline $\begin{array}{l}\text { Samarkand - Sarmishsay - Nurota } \\
\text { Chashma) - Aydarkul }\end{array}$ & $\begin{array}{l}\text { Forish - Sentob - Nurota - Sarmishsoy - } \\
\text { Samarkand }\end{array}$ & $\begin{array}{l}5 \text { day } \\
\text { itinerary }\end{array}$ & Samarkand: Hotel \\
\hline & $\begin{array}{l}\text { Samarkand - Forish - Aydarkul - Nurota } \\
\text { - Bukhara }\end{array}$ & 2 day route & In Jizzakh region: \\
\hline $\begin{array}{l}\text { Samarkand - Karmana - Sarmishsoy - } \\
\text { Bukhara }\end{array}$ & 2 day route & Hotel, Palatka. \\
\hline & $\begin{array}{l}\text { Bukhara - Nurota - Langar - } \\
\text { Sangijumon - Sarmishsoy - Samarkand }\end{array}$ & 3 day route & Navoi Region: Otov, \\
\hline
\end{tabular}

In our opinion, it is necessary to develop all tourist routes starting from Navoi region. The reason is that foreign and domestic citizens and visitors of the FIEZ «Navoi», which started its activity, need to start tourist routes in Navoi city. This is a great opportunity for tourism development. Only use it wisely(Draper, 1997; Sobirov, 2018b).

In analyzing the state of environmental tourism in the Navoi region, it is worth noting that the infrastructure directly aimed at eco-tourism is relevant. Because in Kanimekh and Nurata districts there are several excursions in areas adjacent to Aydarkul. The following table shows the characteristics of the area, such as the buildings built here, camels used as carts, and the nationality of the habitats. (Table 2).

Table 2

Available habitat for ecotourists ${ }^{2}$

\begin{tabular}{|l|l|l|l|}
\hline & Name of business entities & $\begin{array}{l}\text { Tourist Recreation } \\
\text { Facilities }\end{array}$ & Purpose \\
\hline & AYDAR-1 tourist base & 12 yards & Extreme and ecotourism \\
\hline & AYDAR-2 tourist base & 8 boots & Extreme and ecotourism \\
\hline & KAMEL tourist base & 17 yards & Extreme and ecotourism \\
\hline & Total & 37 yards & \\
\hline
\end{tabular}

It is advisable to establish forestry in the areas where desertification and hills are difficult. It is necessary to study the necessity of establishing protected areas in these forest enterprises and their use as tourist sites.

Taking into account the low tourist flow in ecotourism and the remote location of these facilities, communal services have been developed to accommodate tourists in the remote areas of Navoi region using alternative energy sources. On the basis of this, a new tourist map has been created based on the tourist routes and destinations of Navoi region. As the routes created pass through the mountainous areas of the Sarmishsay Gorge, it is suggested to develop the sport of mountaineering. It is recommended to develop cycling on the routes of Bukhara - Nurota - Langar - Sangijumon - Sarmishsay - Samarkand, which consist of Nurata flat plains.

${ }^{1}$ Жадвал маълумотлари муаллифнинг кузатуви натижасида ишлаб чиқилган.

${ }^{2}$ Маълумотлар муаллифнинг экспедицияси натижасида олган ахборотлари асосида тузилган. 
All of this has been proposed to create Guest Homes, which will be posted on internet sites and created using innovative 3-D technology. This will enable people with disabilities to access environmental resources and provide tourists with a glimpse of their visibility without visiting these facilities.

In Kanimekh and Nurata districts, adjacent to Aydarkul, several built facilities are designed to be used as vehicles. Along the proposed routes, the Navoi region's governor advised entrepreneurs to set up "Guest Homes" on October 12, 2017 in residential areas for tourists and tourists, thus creating jobs in remote desert areas. Based on the need to create encyclopedic audio and video films on tourist routes in order to develop domestic tourism in the region and effectively use its tourist potential (historical, cultural, environmental, etc.) and regularly broadcast them on regional and national radio, television and other media. mechanism.

\section{ANALYSIS}

The SWOT analysis of ecological tourism in Navoi region and its positive and negative effects on the natural areas where tourist facilities are located. The SWOT analysis of environmental tourism in the region has been developed, taking into account all aspects of the development of environmental tourism in Navoi region. It also considered the strengths, opportunities, weaknesses and various threats of the sector's development, and analyzed all the points sufficiently.

When a system of factors influencing the development of ecological tourism was developed, the main ones were as follows:

- availability of ecotouristic resources;

- degree of organization of ecological tourism;

- Availability of various resources (state, collective, private, foreign) for the development of ecotourism;

- Creation of appropriate infrastructure for development of ecological tourism;

- preservation of original cultural values and way of life of the local population;

- development of the ecological tourism market.

- These factors are closely related to each other and are expressed as follows (Figure 3).

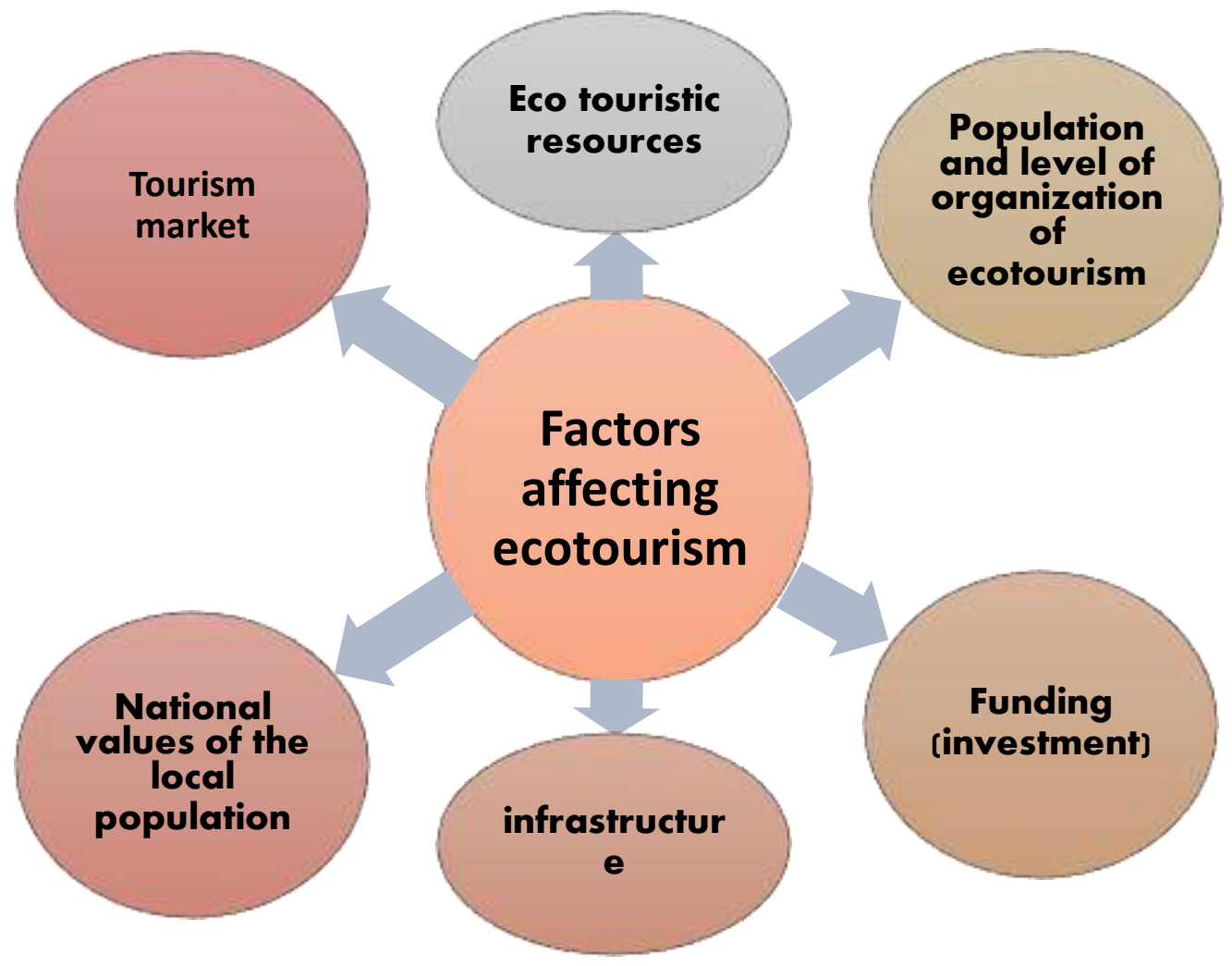

Figure 3. Factors affecting ecological tourism

Taking into account the need for development of all types of tourism in Navoi region, including ecotourism, it is necessary to pay special attention to the allocation of land, financing, development of new tourist routes, attraction of investments from various sources. it is necessary to bring it together. Due to the need to develop environmental tourism in Navoi region, specific strategic directions have been identified. 
The study of ways to improve the organizational and economic mechanisms for the development of environmental tourism in the Navoi Free Economic Zone has come to a number of scientific and theoretical and practical conclusions.

By developing environmental tourism in Navoi region and creating new jobs, we can create new opportunities for employment, economic growth in the region, and improved social lives.

The results of the study showed that the content, types and characteristics of ecological tourism, organizational and economic mechanisms for the development of ecological tourism, the role and role of eco-tourism in the service system in the free economic zone in Navoi region, the specifics of ecological tourism and the region. The importance of socio-economic life should be investigated scientifically and this issue should be covered in the economic literature.

\section{CONCLUSION}

The creation of a free economic zone in Navoi region is also a great opportunity for foreign workers to develop all types of tourism, including environmental tourism.

In the Navoi region the types of eco-tourism objects were studied and improved classifications were developed, which diversified through exotic zones and adventurous tourism, tourism of cultural and social values, recreational and agritourism, and used them for the development of eco-tourism. It would have a great economic effect.

\section{REFERENCES}

1. 1.di Cugno, S., Mantellini, S., \& Berdimuradov, A. (2013). Traditional Techniques, Resources Exploitation and Archaeological Record: an Ethnographical Study from the Oasis of Samarkand (Uzbekistan). In Ethnoarchaeology: Current Research and Field Methods. Conference Proceedings, Rome, Italy, 13th-14th May 2010 (pp. 99-106).

2. Draper, D. (1997). Touristic development and water sustainability in banff and canmore, Alberta, Canada. Journal of Sustainable Tourism, 5(3), 183-212. https://doi.org/10.1080/09669589708667285

3. Kalpakjian, S., \& Schmid, S. (2014). Manufacturing engineering and technology. Retrieved from https://www.researchgate.net/profile/Vijay_Sekar2/publication/262156319_Manufacturing_Engi neering_and_Technology/links/00b49536c9c352428b000000.pdf

4. Novak, J., \& Schwabe, G. (2009). Designing for reintermediation in the brick-and-mortar world: Towards the travel agency of the future. Electronic Markets, 19(1), 15-29. https://doi.org/10.1007/s12525-009-0003-5

5. Page, S. J. (1994). Tourism: Principles and practice. Tourism Management, 15(3), 235-237. https://doi.org/10.1016/0261-5177(94)90115-5

6. Sahadeo, J., \& Zanca, R. (2007). Everyday life in Central Asia: Past and present. Retrieved from https://books.google.com/books?hl=en\&lr=\&id=AbnwAAAAQBAJ\&oi=fnd\&pg=PP2\&dq=uzb ekistan+central+asia\&ots=oz9xDexw6z\&sig=kbBw_iP_wmDAQEwT1S7JatYHPJM

7. Simpfendorfer, B. (2011). The New Silk Road: How a rising Arab world is turning away from the West and Rediscovering China. Retrieved from https://books.google.com/books?hl=en\&lr=\&id=8wHwwdJTUvkC\&oi=fnd\&pg=PP1\&dq=touris $\mathrm{m}+$ silk+road+springer\&ots=ghE0jsF_7g\&sig=pQQQSNpt_njv3ZOe8tEBF8K8y4c

8. Sobirov, B. (2018a). The concept of the tourist economic zone. Case of Uzbekistan. World Scientific News.

9. Sobirov, B. (2018b). The concept of the tourist economic zone. Case of Uzbekistan. World Scientific News, 98(April), 34-45.

10. Rashidov MK "The classification theory of free economic zones". SERVIS- \# 4. 2017. - Page 15

11. Islamova R.A. Problems of development of ecological tourism. Monograph. // T .: "Economy" Publishing House, 2014. 